\title{
ON THE GENUS ENTOSTHODON (FUNARIACEAE, MUSCI) IN THE CAUCASUS
}

\section{О РОДЕ ENTOSTHODON (FUNARIACEAE, MUSCI) HA КАВКАЗЕ}

\author{
V.E. Fedosov ${ }^{1}$, E.A. IGNATOVA ${ }^{1}$, M.S. IGNATOV ${ }^{2} \&$ G.YA. DOROSHINA $^{3}$ \\ В.Э. ФЕДОСОВ ${ }^{1}$, Е.А. ИГНАТОВА ${ }^{1}$, М.С. ИГНАТОВ ${ }^{2}$, Г.Я. ДОРОШИНА ${ }^{3}$
}

Abstract

The genus Entosthodon Schwägr. is represented in the Caucasus by six species, among them only E. muhlenbergii has been known for the territory until now. Entostodon fascicularis is excluded from the Caucasian moss flora, as all so-called specimens are re-identified as $E$. handelii, a species new for Russia. Three new species, Entosthodon dagestanicus, E. abramovae and E. stenophyllus, are described and illustrated. Entosthodon hungaricus is found in the region for the first time. The identification key is given for the Entosthodon species from the Caucasus and neighboring areas.

Резюме

Род Entosthodon Schwägr. на Кавказе представлен шестью видами, из которых ранее для этой территории приводился только E. muhlenbergii. Entostodon fascicularis исключен из бриофлоры Кавказа, образцы, ранее относимые к этому виду, переопределены как E. handelii, который приводится для России впервые. Описаны три новые для науки вида - Entosthodon dagestanicus, E. abramovae и E. stenophyllus, даны их диагнозы и иллюстрации. Впервые для Кавказа приводится E. hungaricus. Дан ключ для определения видов Entosthodon на Кавказе и в сопредельных районах.

KEYWORDS: Caucasus, Entosthodon, Funariaceae, mosses, new species, taxonomy

The check-list of East Europe and North Asia (Ignatov, Afonina, Ignatova et al., 2006) included only two species of Entosthodon for the Russian Caucasus: E. muhlenbergii (Turner) Fife and E. fascicularis (Hedw.) Müll. Hal. In the course of our exploration of the moss flora of Gunib Plateau in Dagestan (cf. Ignatov et al., 2010) as much as five species of Entosthodon were revealed. Two of them were identified as E. muhlenbergii and E. handelii (Schiffn.) Laz., the latter being the first record for the Russian moss flora. Three other species did not fit any known taxa. Although collections are not big, the combinations of characters are peculiar enough to describe them as species new to science. In addition, E. hungaricus was found in a foothill part of Dagestan, being the species new for the Caucasus. The description of species is given below, supplemented with the key that includes some other species reported from the neighboring areas.

1 - Moscow State University, Biological Faculty, Geobotany Dept., Moscow 119991 Russia - Россия 119991 Москва, Московский государственный университет, Биологический факультет, каф. геоботаники; е-таils: fedosov_v@mail.ru \& arctoa@list.ru

2 - Main Botanical Garden of Russian Academy of Sciences, Botanicheskaya 4, Moscow 127276 Russia Россия 127276 Москва, Ботаническая, 4, Главный ботанический сад PAH; e-mail: misha ignatov@list.ru

3 - V.L. Komarov Botanical Institute Rus. Acad. Sci., Prof. Popov Str., 2, St. Petersburg, 197376 Russia Россия 197376, г. Санкт-Петербург, ул. Проф. Попова, д. 2, Ботанический институт им. В.Л. Комарова PAH; e-mail: marushka-le@mail.ru 
Entosthodon abramovae Fedosov \& Ignatova sp. nov. Figs. 1, 6: 1-4

A pluribus speciebus generis Entostodone combinatio cellulis exothecio tenuissimis et sporis parvis et a E. angustifolio peristomio duplici, a E. stenophyllo peristomio dentibus minus evolutis et sporis parvis et a speciebus ambis foliis latioribus ovoideis usque obovoideis parte supero margino dentate et reti cellulari brevioribus et latioribus.

Type: RUSSIA, Dagestan Republic, Gunib District, rocky creek canyon near road between Shamil's gate and the Mountain Botanical Garden station $\left(42^{\circ} 23^{\prime} \mathrm{N}-46^{\circ} 56^{\prime} \mathrm{E}\right), 1440 \mathrm{~m}$. alt., on shaded moist calcareous fine soil at the cliff base, 26.V.2010, Fedosov \#10-2-8 (Holotype in MW).

Ethymology: in honor of Anastasiya Lavrentievna Abramova, bryologist of the USSR and Russia.

Plants pale-green to whitish, in loose tufts. Stems 2-4 mm, green to brownish at base. Leaves crowded in distal part of stem, contorted when dry, erect-spreading when moist, (1.8-)2.0-2.4(-2.5)×(0.7-)0.8-1.1(-1.2) $\mathrm{mm}$, ovate-lanceolate to ovate or obovate-lanceolate, short acuminate to apiculate; margins slightly serrate to subentire, in upper part indistinctly bordered; costa moderately strong, reaching ca. 5/6 the leaf length; laminal cells (45-)50-75(-80)×(17-)20-27(-32) $\mu \mathrm{m}$, rectangular to hexagonal or rhombic, thin-walled; marginal cells not or indistinctly differentiated in 1(-2) rows, narrower than laminal cells, (55-)65-90(-105) $\times(7-) 10-17(-20) \mu \mathrm{m}$, rectangular to elongate, with oblique transverse walls and protruding upper angles; basal cells $24-39 \times(19-) 24-30(-35) \mu \mathrm{m}$, quadrate to short-rectangular, alar cells usually indistinctly differentiated, subquadrate, occasionally with 3-5 large, thin-walled, inflated cells. Synoicous. Seta 4-6 cm, straight, yellow to brownish. Capsule yellow to brownish, erect to slightly inclined, straight, symmetric, ca. $2.0 \mathrm{~mm}$ long, elongate-pyriform, slightly narrowed to mouth, neck equal to urn, exothecial cells below mouth short-rectangular to transversely rectangular, thick-walled, brownish; in upper part of urn (35-)40$60(-65) \times 9-17 \mu \mathrm{m}$, rectangular to elongate hexagonal, thin-walled at frontal view, in transverse section with semicircular thickening of outer and partly radial cell walls; annulus not conspicuously differentiated. Peristome reduced, double, exostome teeth to $75 \mu \mathrm{m}$ long, obtuse, fragile, partly adherent to endostome segments, orange, longitudinally and obliquely striolate; endostome segments $40-75 \mu \mathrm{m}$ long, broader than exostome teeth, partly laterally fused at bases, orange to whitish with age, finely papillose. Operculum low conic. Calyptra cucullate. Spores 18-23 $\mu \mathrm{m}$, with low papillae.

Differentiation. Entosthodon abramovae differs from most other species of the genus by combination of (1) straight capsule; (2) rudimentary double peristome; (3) relatively small spores, 17-23 $\mu \mathrm{m}$ (mostly 21-22 $\mu \mathrm{m}$ ), and semilunar exothecium thickenings resulting in a thin-walled appearance of cells as seen from the front. In fact, there is rather apparent correlation between a thickening pattern and front appearance, usually a cuneiform thickening results in a slit-like lumen. However, the correlation between these patterns is not absolute.

The differences from E. angustifolius Jur. \& Milde (according to a description and illustrations of Abramov et al., 1989) include: (1) leaves ovate-lanceolate to ovate or obovate-lanceolate vs. lanceolate; (2) peristome double vs. simple; (3) spores $18-23 \mu \mathrm{m}$ vs. $14-18 \mu \mathrm{m}$. A somewhat similar North American species E. rubiginosus (R.S.Williams) Grout and E. tucsoni (Bartram) Grout (according to the description and illustrations of Miller \& Miller, 2007) differ in (1) thickwalled exothecial cells and (2) larger spores, 25$40 \mu \mathrm{m}$ vs. $18-23 \mu \mathrm{m}$.

Entosthodon dagestanicus Fedosov \& Ignatova sp. nov. Figs. 2, 6: 5-6

A E. muhlenbergio simili, sed cuis absentia margine; a E. commutato apice folio piliforme dentate ejus et a speciebus ambis peristomio minus evoluto et cellula exothecio parietibus tenuioribus differt.

Type: RUSSIA, Dagestan Republic, Gunib District, rocky creek canyon near road between Shamil's gate and the Mountain Botanical Garden station $\left(42^{\circ} 23^{\prime} \mathrm{N}-46^{\circ} 56^{\prime} \mathrm{E}\right), 1440 \mathrm{~m}$. alt., on shaded moist calcareous fine soil at the cliff base, 26.V.2010, Fedosov \#10-2-161 (Holotype in MW).

Plants light green, growing in loose tufts or as scattered individuals. Stems 3-5 mm, pale green, at base brownish. Leaves crowded in distal part of stem, erect-appressed when dry, erect-spreading when moist, (2.2-)2.4-2.9(-3.3) $\times(0.7-) 0.8-1.0(-1.1) \mathrm{mm}$,

Fig. 1. Entosthodon abramovae sp. nov. (from holotype). 1 - habit, dry; 2 - habit, wet; 3 - capsule; 4, 6 - parts of peristome; 5 - exothecium transverse section; 7 - exothecial cells; 8 - upper leaf cells; 9 - median laminal cells; 10-11 - leaves; 12 - basal leaf cells. Scale bars: $5 \mathrm{~mm}$ for 1-2; $2 \mathrm{~mm}$ for 10-11; $1 \mathrm{~mm}$ for 3; $100 \mu \mathrm{m}$ for 7-9, 12; $50 \mu \mathrm{m}$ for 4-6. 


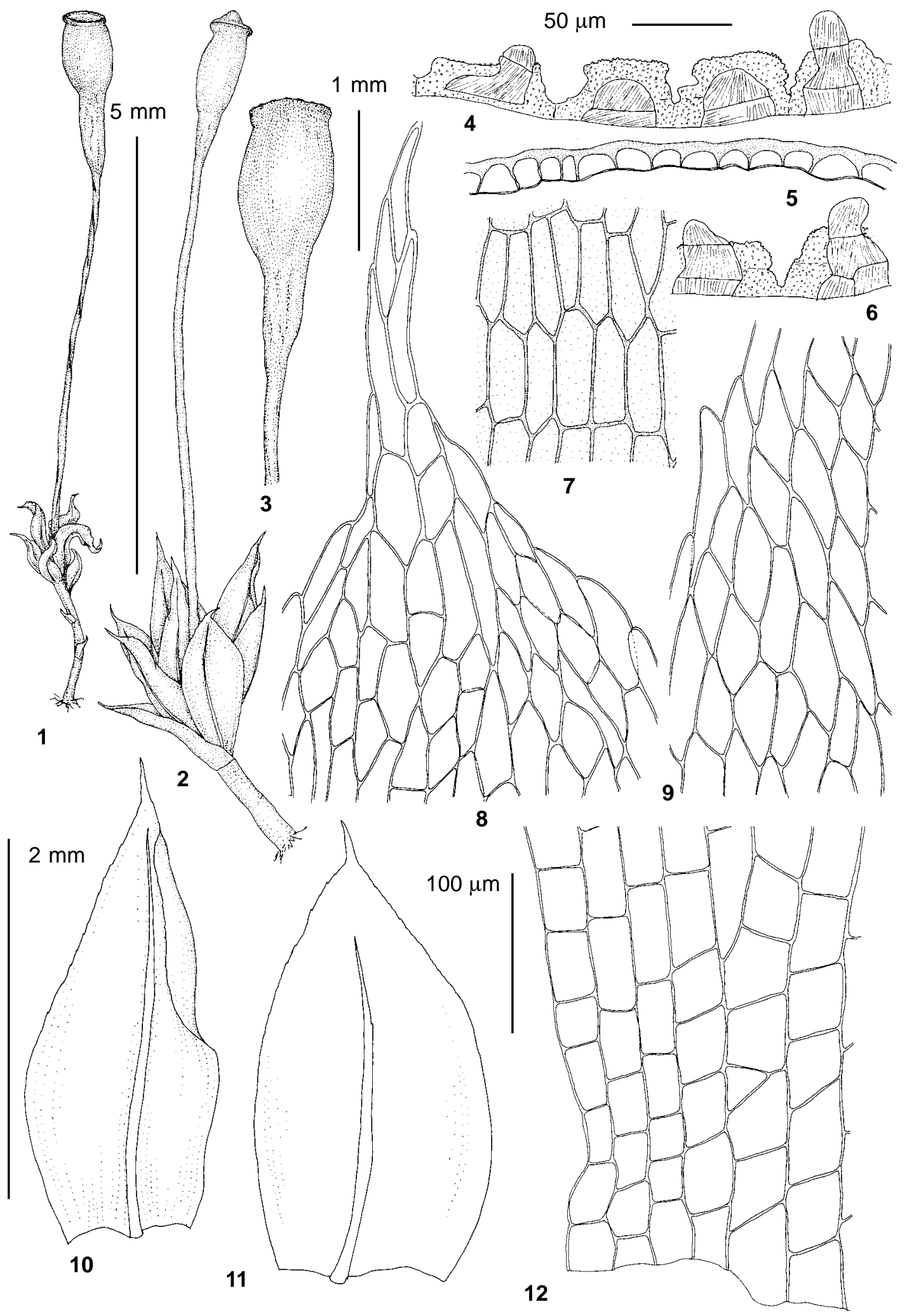



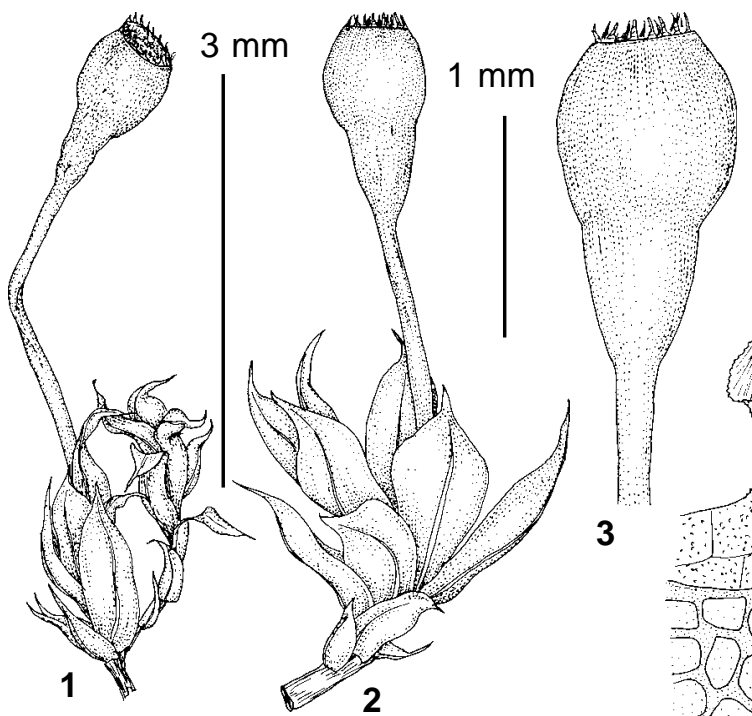

3
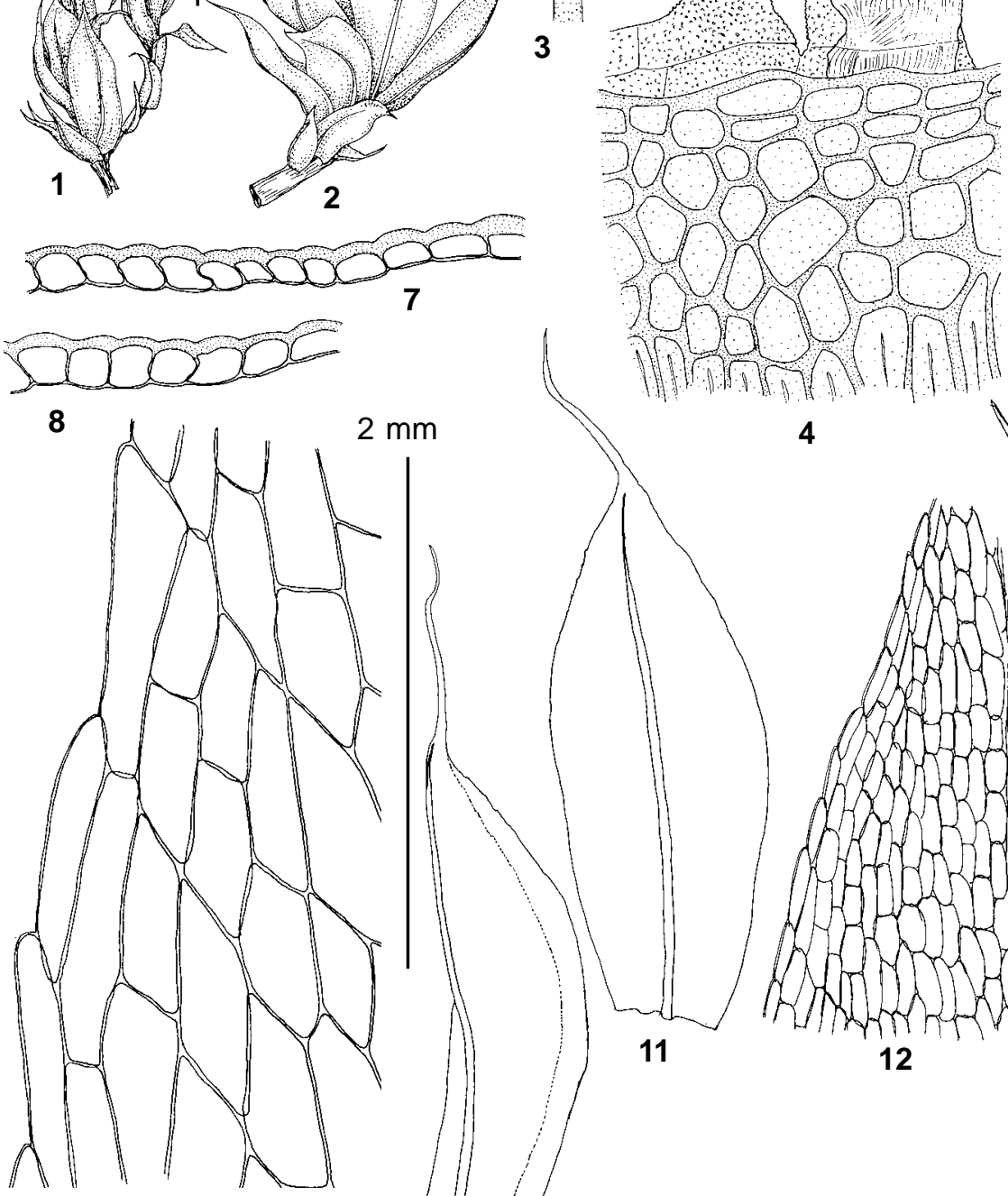

9

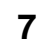

$\mathrm{mm}$ 
elliptic, ovate-lanceolate to obovate-lanceolate, abruptly narrowed into yellowish filiform acumen 0.2$0.3 \mathrm{~mm}$ long; margins entire proximally, crenulate medially, serrate distally, border undifferentiated; costa narrow, green to reddish-brown, ending shortly below acumen base to, more commonly, percurrent; median laminal cells(50-)60-85(-95)×(19-)21-24(-27) $\mu \mathrm{m}$, irregularly rectangular to elongate hexagonal, thin-walled; marginal cells inflated, with oblique transverse walls and protruding upper angles, forming rather obtuse or sharp teeth; cells near leaf apex 44-61×17-25 $\mu \mathrm{m}$, rhombic; basal cells (36-)40-56 $(-61) \times 21-31 \mu \mathrm{m}$, short rectangular, alar cells obscurely differentiated, (12-)15-20(-22) $\times 17-25 \mu \mathrm{m}$, quadrate to transversely rectangular. Synoicous. Setae 2-3 $\mathrm{mm}$, reddish brown proximally, yellowish distally, straight or slightly curved distally. Capsules reddish brown, erect to slightly inclined, 1.0-1.5 mm long, pyriform, symmetric, narrowed to mouth, with neck equal to urn; exothecial cells below mouth transversely rectangular in several rows, thick-walled, brownish, in upper part of urn $31-37 \times 10-13 \mu \mathrm{m}$, rectangular to elongate-hexagonal, thick-walled with slit lumen in frontal view, in transverse section with uniformly incrassate outer cell wall or thickening of semilunar shape; annulus not conspicuously differentiated. Peristome reduced, double, exostome teeth to 100 $\mu \mathrm{m}$ long, fragile, adherent to outer surface of endostome segments, orange, longitudinally and obliquely striolate; endostome segments $140-150 \mu \mathrm{m}$ long, orange to whitish with age, finely papillose. Operculum not seen. Calyptra cucullate. Spores 24$32 \mu \mathrm{m}$, mostly $28-30 \mu \mathrm{m}$, with apparent triradiate scar, papillose throughout or proximal pole almost smooth, while distal pole always distinctly papillose.

Differentiation. This new species is characterized by a combination of symmetric capsule and moderately reduced peristome which does not exceed $150 \mu \mathrm{m}$. It differs from the North American E. planoconvexus (Bartram) Grout in (1) less developed fused peristome and (2) larger spores, 24$32 \mu \mathrm{m}$ vs. $20-25 \mu \mathrm{m}$ in E. planoconvexus (Miller $\&$ Miller, 2007). The differences from E. attenuatus (Dicks.) Bryhn include: (1) leaf apex filiform vs. acute; (2) leaf margins not bordered, serrate vs. bordered, nearly entire; (3) shorter peristome, $150 \mu \mathrm{m}$ vs. ca. $180 \mu \mathrm{m}$ in E. attenuatus. Characters differentiating it from E. commutatus Durieu $\&$ Mont are as follow: (1) costa ends just below filiform acumen to percurrent vs. ending well below apex; (2) less developed peristome, up to 150 $\mu \mathrm{m}$ versus ca. $320 \mu \mathrm{m}$ in E. commutatus.

Leaf characters (long costa, serrate margin, very long apical cells, often longer than $300 \mu \mathrm{m}$ ) and spore ornamentation indicate close affinity of. E. dagestanicus with E. muhlenbergii. However the latter species has a well developed double peristome, is much larger in plant size (e.g. seta is longer than $1 \mathrm{~cm}$, while in E. dagestanicus it is $2-3 \mathrm{~mm}$ only), leaf border well differentiated vs. undifferentiated, and somewhat smaller spores [according to publications ranging from 19-22 $\mu \mathrm{m}$ (Brugués \& Ruiz, 2010) to 18-28(-30) $\mu \mathrm{m}$ (Smith, 2004), while in Caucasian plants of E. muhlenbergii they were found to be $19-25 \mu \mathrm{m}$, mostly 20-24 $\mu \mathrm{m}]$.

Entosthodon stenophyllus Fedosov \& Ignatova, sp. nov.

Fig. 3

Species proxima a E. angustifolio sed cuis sporis majoribus et peristomio duplici cum dentibus bene evolutis; a E. commutato peristomio dentibus uniseriatis minus evolutis et cellulis exothecio tenuioribus differt.

Type: RUSSIA, Dagestan Republic, Gunib District, roadside between Gunib and the station of the Mountain Botanical Garden near the Shamil's portrait $\left(42^{\circ} 23^{\prime} \mathrm{N}-46^{\circ} 58^{\prime} \mathrm{E}\right), 1330 \mathrm{~m}$ alt., on calcareous loamy-placer slope, 26.V.2010, Fedosov \#10-2-5 (Holotype in MW).

Plants light green, in low loose tufts. Stems 4$7 \mathrm{~mm}$, light-green, at base brownish. Leaves rather evenly arranged along stem, gradually enlarging and more or less crowded distally, erect to appressed when dry, erect-spreading when moist, (2.0-)2.2-2.8 $(-3.3) \times(0.4-) 0.5-0.6(-0.65) \mathrm{mm}$, lanceolate to linearlanceolate, acuminate; margins entire, border undifferentiated; costa weak, greenish to yellowish-brown, reaching about 5/6 the leaf length; median and upper laminal cells (50-)55-75(-85) $\times(10-) 12-17(-22) \mu \mathrm{m}$, elongate, thin-walled; basal leaf cells slightly wider, rectangular. Synoicous. Setae 4-8 mm, straight, yellow to brownish. Capsules yellow-brown, erect or somewhat inclined, straight, symmetric, elongatepyriform, 1.5-2.0 mm, slightly constricted at mouth; neck as long as urn; exothecial cells below mouth wider, short rectangular to transversely rectangular, thick-walled, brownish; in upper part of urn 34$54 \times 8-13 \mu \mathrm{m}$, elongate, at frontal view moderately thin-walled; in transverse section with cuneiform thickenings; annulus not conspicuously differentiated. Peristome reduced, double; exostome teeth to 

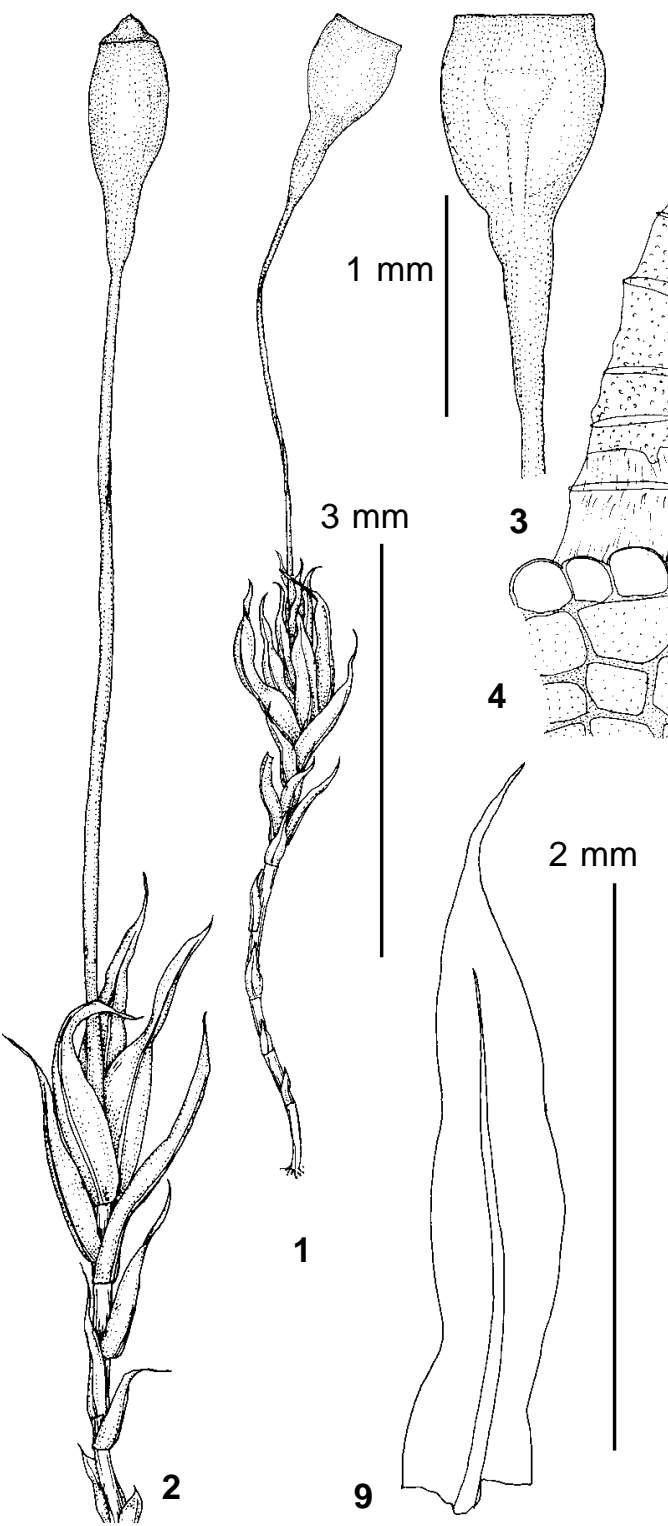

$75 \mu \mathrm{m}$ long, fragile, adherent to endostome segments, orange, longitudinally and obliquely striolate; endostome segments 40-75 $\mu \mathrm{m}$ long, orange to whitish with age, finely papillose. Operculum low conic. Calyptra cucullate. Spores 24-32 $\mu \mathrm{m}$, papillose.

Differentiation. Entosthodon stenophyllus is close to E. angustifolius, but differs in (1) \pm developed double peristome, ca $75 \mu \mathrm{m}$ in open old capsules vs. rudimentary, simple one, hardly protruding over urn mouth (Abramov et al., 1989), and (2) spores 24-32 $\mu \mathrm{m}$ vs. (14-) 16-18 $\mu \mathrm{m}$. Other Entosthodon species have broader leaves with more or less serrulate or crenulate margins, while the leaf margin is conspicuously entire in these two species.

Entosthodon handelii (Schiffn.) Laz., Zhurn. Inst. Bot. Vseukrajins'k. Akad. Nauk 26. 27: 207. 1938. - Funaria handelii Schiffn., Ann. Naturhist. Hofmus. 27: 493. 61-69. 1913.

Fig. 4

Plants green to whitish, in loose tufts. Stems 4-7 $\mathrm{mm}$, green, yellowish to brownish to base. Leaves crowded in distal part of stem, erect to somewhat contorted when dry, spreading when moist, (1.5-)1.7$2.2(-2.8) \times(0.7-) 0.8-1.0(-1.2) \mathrm{mm}$, ovate-lanceolate or obovate-lanceolate to obovate, often slightly 
constricted in middle part, shortly acuminate; margins indistinctly bordered, with one row of yellowish cells, entire or crenulate to serrulate distally; costa weak, green to brownish, reaching $2 / 3-5 / 6$ the leaf length; median leaf cells (45-)55-70(-80) $\times 20-30 \mu \mathrm{m}$, irregular, elongate-hexagonal to short-rectangular, thin-walled; cells just below acumen shorter, (35-) $40-50(-56) \times 20-27 \mu \mathrm{m}$, with slightly incrassate walls, rectangular to rhombic; marginal cells indistinctly differentiated in middle part of leaf and occasionally distally, being yellowish, somewhat inflated, and in one row somewhat longer, (50-)65-90(-100)×9-19 $\mu \mathrm{m}$; basal cells (75-) 85-115(-135)×(15-)17-25(-29) $\mu \mathrm{m}$, rectangular; alar cells not or indistinctly differentiated, formed by 3-5 inflated larger cells. Synoicous. Setae 0.7-1.3 cm, straight, yellow or reddish to brownish. Capsule yellowish to brownish, erect or somewhat inclined, straight, but usually slightly asymmetric or sometimes very slightly curved, 1.8-2.5 mm, elongate-pyriform, neck as long as urn, rounded to mouth, but after spore release with wide mouth; exothecial cells below mouth in 4-5 rows transversely rectangular, thick-walled, brownish, in upper part of urn 35-60×7-13 $\mu \mathrm{m}$, rectangular to elongate-hexagonal, at frontal view thin-walled, in transverse section with cuneiform thickenings; annulus not conspicuously differentiated. Peristome strongly reduced, double, exostome teeth to ca. $75 \mu \mathrm{m}$, adherent to segments, orange, longitudinally and obliquely striolate; endostome segments 40-75 $\mu \mathrm{m}$, wider than teeth, laterally fused by their bases, orange to whitish with age, finely papillose. Operculum plane-convex. Calyptra cucullate. Spores 27-35 $\mu \mathrm{m}$, coarsely papillose.

Differentiation. Entosthodon handelii can be confused with E. obtusus (Hedw.) Lindb., E. fascicularis, E. durieui and E. abramovae. It differs:

- from E. obtusus in (1) leaf margins distinctly serrate distally vs. entire to weakly serrulate; (2) capsule elongate-pyriform with neck equal to urn vs. ovate-pyriform with neck shorter than urn;

- from E. fascicularis in (1) capsule elongate-pyriform with neck equal to urn vs. ovatepyriform with neck shorter than urn; (2) exothecial cells elongate vs. predominantly isodiametric;

- from E. durieui in (1) leaves ovate to ovatelanceolate with maximal width in proximal part of leaf vs. obovate with maximal width in distal part of leaf; (2) margins with one row of yellowish cells, forming indistinct border, serrate due to protruding cell angles distally vs. not bordered or indistinctly bordered by thin-walled, somewhat elongate, narrowed cells of the same color as lamina, entire to crenulate due to inflated outer cell walls distally; (3) costa reaching 5/6 the leaf length to ending just below apex vs. about $1 / 2$ the leaf length;

- from E. abramovae in (1) narrower leaves, predominantly ovate-lanceolate vs. ovate; (2) margins bordered by one row of yellowish cells vs. not bordered or indistinctly bordered by thinwalled cells of the same color as lamina; (3) exothecial cells in upper part of urn more or less thick-walled, cuneiform in transverse section vs. thin-walled, semicircular in transverse section; (4) spores $23-35 \mu \mathrm{m}$, with large papillae vs. 17$23 \mu \mathrm{m}$, smooth or with low papillae.

Distribution. Entosthodon handelii was described by Schiffner (1913) from Mesopotamia and Kurdistan (localities mentioned in protologue are today in Turkey and Iraq territories), and subsequently reported from Jordan, Iran, Afghanistan, Turkmenistan, and Tajikistan. The species grows mostly on calcareous rocks in xeric regions. Plants from Russia agree with the description of Shiffner (1913) in all details. Abramov et al. (1989) reported spores to be $22-26 \mu \mathrm{m}$, but in cited Middle Asiatic specimens (e.g. Turkmenistan, 22.X.1983, Sirotina, LE), according to our measurement, spores are 23-31 $\mu \mathrm{m}$, mostly 26$29 \mu \mathrm{m}$. A revision of herbarium collections revealed that the specimen from Besengi Valley previously reported as E. fascicularis belongs in fact to $E$. handelii.

Specimens examined: RUSSIA: Kabardino-Balkaria: Bezengi River valley, 23.VII.1988, Popova \& Portenier \#40 (MHA); Dagestan Republic: Gunib District, southern slope of Gunib Plateau, on the dolomite cliff ledge near tunnel mouth $\left(42^{\circ} 23^{\prime} \mathrm{N}-46^{\circ} 54^{\prime} \mathrm{E}\right), 1860$ $\mathrm{m}$ alt., on shaded calcareous soil, 25.V.2010, Fedosov \#10-2-6 (MW); same place (42 $\left.23^{\circ} \mathrm{N}-46^{\circ} 54^{\prime} \mathrm{E}\right), 1940$ $\mathrm{m}$ alt., S-facing cliffs, 25.V.2009, Doroshina s.n. (LE).

Entosthodon muhlenbergii (Turner) Fife, J. Hattori Bot. Lab. 58: 192. 1985. - Funaria muhlenbergii Turn., Ann. Bot. (Känig \& Sims) 2: 198. 1804 [1805].

Fig. 5, 6: 7

Plants green to whitish green, in loose to moderately dense tufts. Stems 3-6 mm, green, yellowish to brownish at base. Leaves crowded in distal part of stem, appressed when dry, slightly spreading when moist, (1.8-)2.0-2.4(-2.5) $\times(0.55-) 0.6-0.8(-0.9) \mathrm{mm}$, 


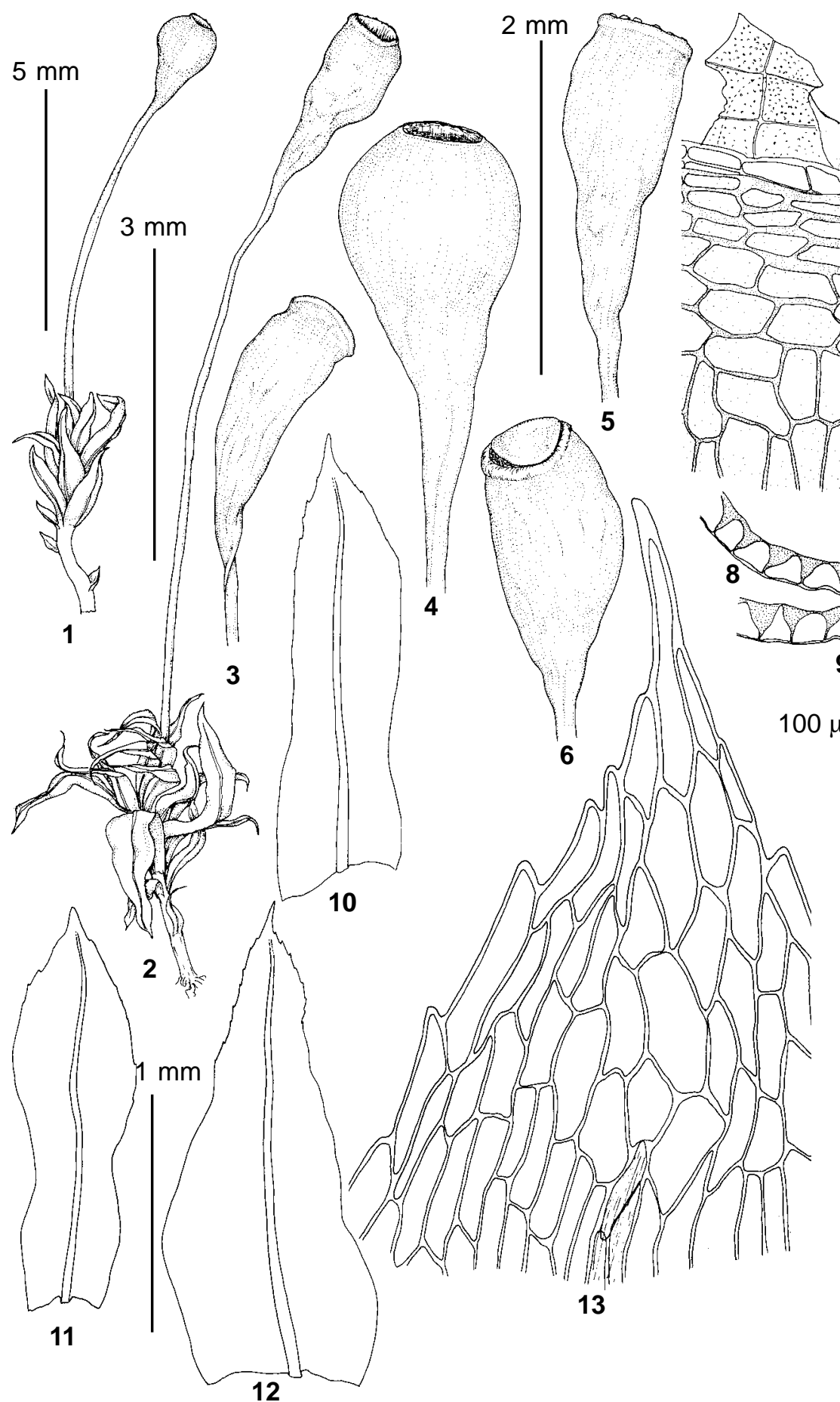

Fig. 4. Entosthodon handelii (Schiffn.) Laz. (from Kabardino-Balkaria, 23.VII.1988, Popova \& Portenier \#40, MHA); 1 - habit, wet; 2 - habit, dry; 3-6 - capsules (3, 5-6 - dry, 4 -wet); 7 - peristome; 8-9 - exothecium transverse section; 10-12 - leaves; 13 - upper laminal cells; 14 - exothecial cells; 15 - basal leaf cells. Scale bars: $5 \mathrm{~mm}$ for $1 ; 3 \mathrm{~mm}$ for $2 ; 2 \mathrm{~mm}$ for 3-6; $1 \mathrm{~mm}$ for $10-12 ; 100 \mu \mathrm{m}$ for 7-9, 13-15. 

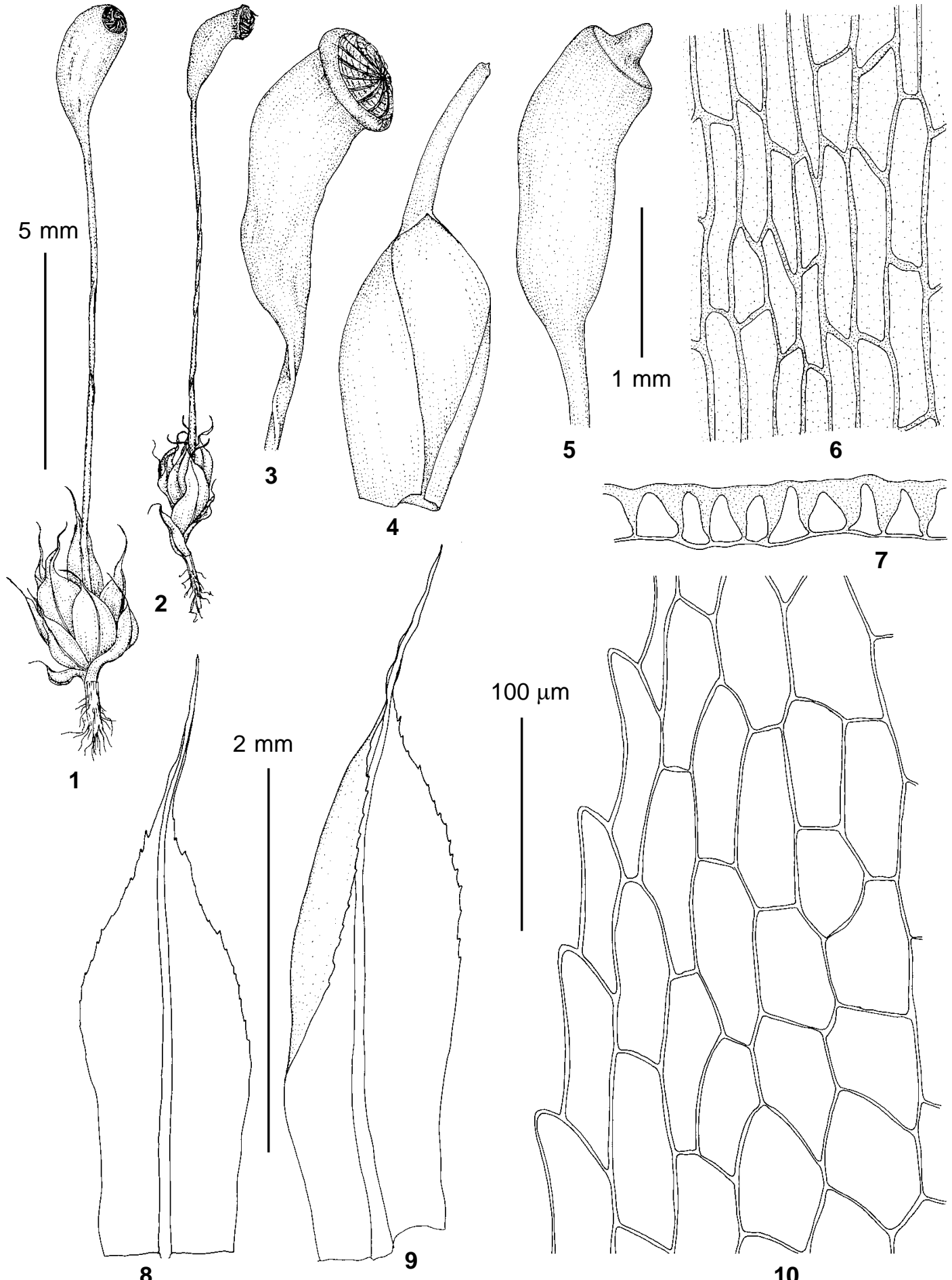

6
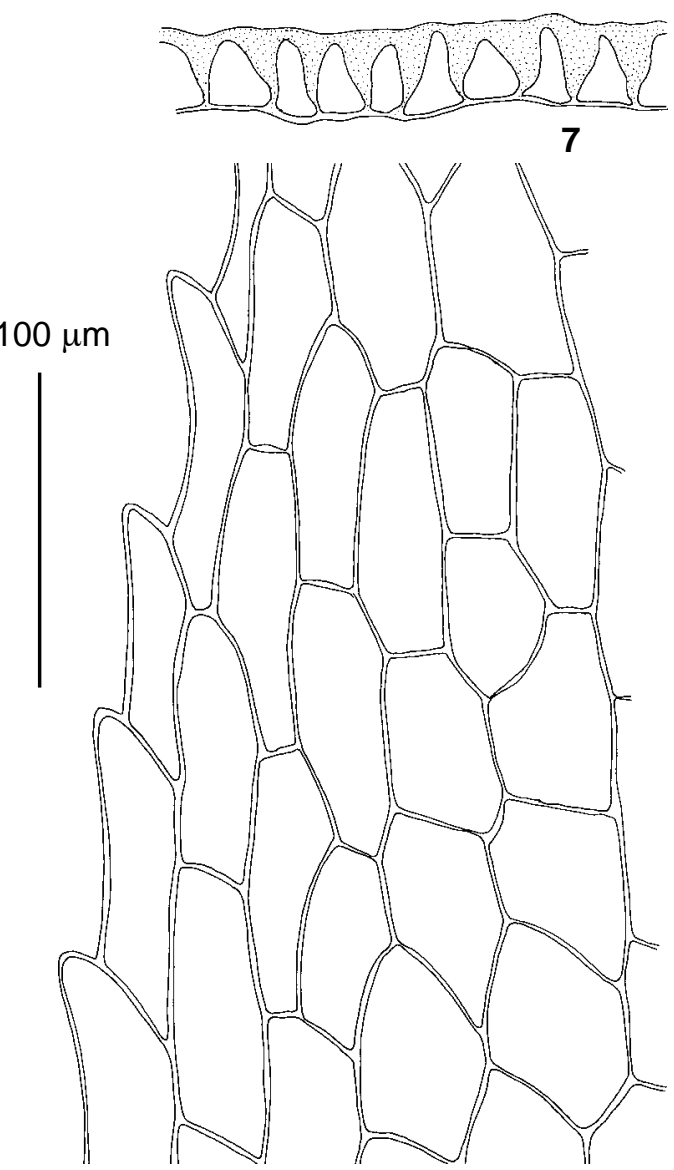

10

Fig. 5. Enthostodon muhlenbergii (Turner) Fife (from Stavropol Territory, Pyatigorsk, 7.V.2009, Doroshina s.n., LE); 1 - habit, wet; 2 - habit, dry; 3, 5 - capsules; 4 - calyptra; 6 - exothecial cells; 7 - exothecium transverse section; 8-9 - leaves; 10 - median laminal cells. Scale bars: $5 \mathrm{~mm}$ for 1-2; $2 \mathrm{~mm}$ for 8-9; $1 \mathrm{~mm}$ for 3$5 ; 100 \mu \mathrm{m}$ for $6-7,10$. 
elliptic, ovate-lanceolate to obovate-lanceolate, abruptly narrowed into yellowish filiform acumen 0.3 $0.55 \mathrm{~mm}$ long; margin entire to crenulate proximally, serrate distally, border in distal part of leaf somewhat differentiated; costa narrow, green to reddish-brown, reaching $4 / 5$ the leaf length, ending shortly below acumen base or, more commonly, percurrent; median laminal cells (40-)50-75(-90) $\times(23-) 25-35(-38) \mu \mathrm{m}$, irregularly elongate-hexagonal to short rectangular, thin-walled; near acumen base 33-50×25-32 $\mu \mathrm{m}$, rhombic, moderately thick-walled; marginal cells moderately differentiated in colour and longer cells, in 1-2(-4) rows brownish, (60-)75-90(-109)×(6-)8$17(-24) \mu \mathrm{m}$, elongate to linear, thick-walled, with oblique transverse walls and protruding apices, forming sharp teeth; basal cells (60-)65-80(-85)×(20-)24$30(-35) \mu \mathrm{m}$, short-rectangular; alar cells indistinctly undifferentiated. Synoicous. Setae 0.5-1.0(-1.2) cm, straight, yellow to reddish or brownish in lower part. Capsule yellowish to brownish, furrowed when dry, erect to somewhat inclined, 2-2.8 mm long, elongatepyriform, curved above middle, neck equal to urn; exothecial cells below urn mouth in 4-5 rows shortrectangular to transversely rectangular, thick-walled, brownish, in the middle part of urn $45-65 \times 12-18$ $\mu \mathrm{m}$, rectangular and elongate hexagonal, at frontal view thick-walled, in transverse section with cuneiform thickening; annulus not conspicuously differentiated. Peristome well developed, double; exostome teeth to $400 \mu \mathrm{m}$ long, orange, hyaline distally, longitudinally and obliquely striolate on outer surface, with prominent ventral trabeculae; endostome segments ca $300 \mu \mathrm{m}$ long, whitish, finely papillose. Operculum low conic, obtuse. Calyptra cucullate. Spores 19-25(-30) $\mu \mathrm{m}$, mostly 20-24 $\mu \mathrm{m}$, with triradiate scar on proximal pole, papillose throughout, but on distal pole stronger.

Differentiation. Due to asymmetric capsule and well developed trabeculate peristome E. $m u$ hlenbergii can be confused only with $E$. pulchellus (H.Philib.) Brugués; it differs from the latter species in \pm distinctly bordered leaves, with margins serrate distally and short to long, filiform, more or less flexuose leaf tips vs. indistinctly bordered leaves, with entire to slightly crenulate margins and acuminate to short filiform, mostly straight leaf tips.

Distribution. The species is widely distributed in xeric areas of the world. It was reported from many regions of Russia, but its old circumscription included also Enthostodon pulchellus.
A subsequent revision revealed that the latter species occurs sporadically in many regions of Russia, while all collections of E. muhlenbergii are from the Caucasus, where E. pulchellus is still not found (cf. Ignatov \& Ignatova, 2003).

Specimens examined: RUSSIA, Stavropol Territory, Pyatigorsk, 7.V.2009, Doroshina (LE); Ossetiya, Mozdok, 14.IV.1891, Lipsky (LE); Dagestan, Chir-Yurt, 13.V.1981, Lypsky (LE); Gunib (42²3’N - 46 ${ }^{\circ} 54^{\prime}$ E) 1940 m, S-facing cliffs, 25.V.2009, Doroshina (LE).

Entosthodon hungaricus (Boros) Loeske, Repert. Spec. Nov. Regni Veg. Sonderbeih. B 3(2): 115. 1929. - Funaria hungarica Boros, Magyar Bot. Lapok 23: 73. 1925. - Physcomitrium longicolle Trab., Rev. Bryol. 29: 64. 1922 [1923]. Entosthodon longicolle (Trab.) Ros \& M.J. Cano, Cryptog. Bryol. 28: 138. 2008, nom. illeg.

Pisarenko et al. (2001) and Ignatov \& Ignatova (2003) reported and illustrated this species from South Siberia and Lower Volga region; these plants have a shorter neck than Caucasian ones. However the capsule structure of plants from Dagestan agrees with E. hungaricus as it has been illustrated by Heyn \& Herrstadt (2004) for Israel and by Brugués \& E. Ruiz (2010) for Iberian Peninsula.

Differentiation From all other Entosthodon species included into the key (see below) E. hungaricus can be easily separated by a combination of not bordered leaves, straight, conic to elongate-pyriform capsules which are widened at mouth, peristome represented only by low membrane, and rostrate operculum.

Distribution. The distribution area of E. hungaricus stretches from Morocco and Iberian Peninsula to southern Siberia (Khakassia), but in many areas it is rare; it occurs mostly in steppe zone.

Specimens examined: RUSSIA: Dagestan Republic, Buinaksk Distr., vicinity of Talgi Settl. (ca. $10 \mathrm{~km}$ to SSW from Mahachkala), Talginskoe Ushzhel'e (42 $\left.52^{\prime} 39.95^{\prime \prime} \mathrm{N}-47^{\circ} 27^{\prime} 22.67^{\prime \prime} \mathrm{E}\right), 530 \mathrm{~m}$. alt., on dry bottom of pool, with Bryum argenteum, Didymodon cf. rigidulus, and Tortula inermis, Fedosov \#10-2-149 (MW); same place, on slope of dry creek bank, with Bryum sp., Fedosov \#10-2-150 (MW).

\section{SPECIES EXCLUDED}

Entosthodon fascicularis (Hedw.) Müll. Hal. was reported from Bezengi Valley in KabardinoBalkaria (Kharzinov et al., 2006), but subsequently the specimen was re-identified as E. handelii. 

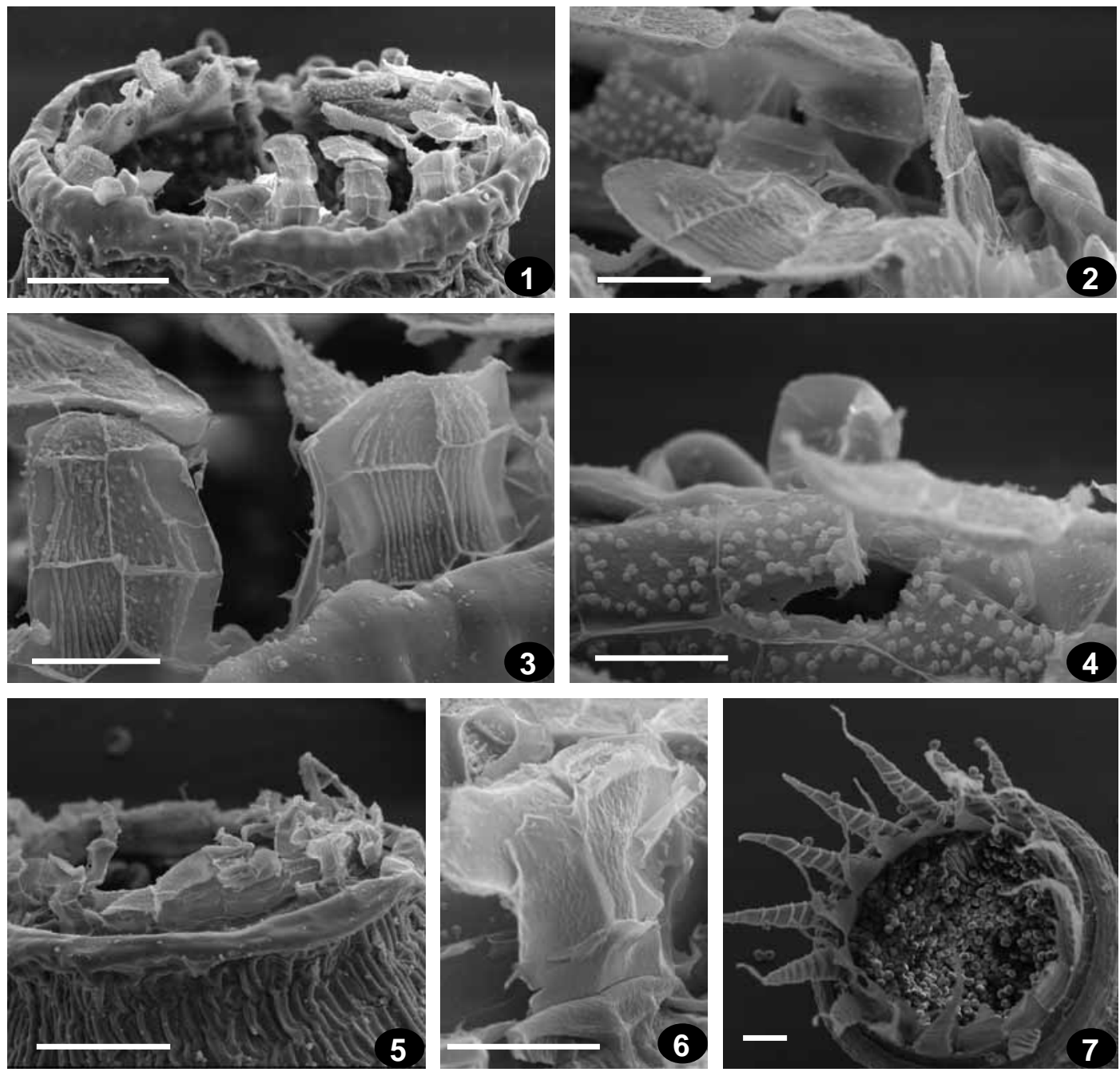

Fig. 6. 1-4: Entosthodon abramovae sp. nov. (from holotype); 5-6: E. dagestanicus sp. nov. (from holotype); 7: E. muehlenbergii (from Stavropol Terr., 7.V.2009 Doroshina, LE). 1, 5, 7 - peristomes; 2 -exostome teeth, side view; 3, 6 - exostome teeth from outside; 4 - basal membrane fragment from inside. Scale bars: 1, 5, $7-100 \mu \mathrm{m} ; 2-4,6-20 \mu \mathrm{m}$.

KEY FOR IDENTIFICATION OF ENTOSTHODON SPECIES IN RUSSIA AND NEIGHBORING REGIONS

1. Capsule symmetric or occasionally slightly asymmetric; peristome rudimentary or, if well developed, mostly shorter than $250 \mu \mathrm{m}$ (except E. commutatus)

2

- Capsule markedly asymmetric, peristome longer than $250 \mu \mathrm{m}$

2. Peristome reduced, rarely \pm well-developed, teeth shorter than $100 \mu \mathrm{m}$ 3

- Peristome well-developed, teeth longer than $100 \mu \mathrm{m}$ 11
3. Capsule short-pyriform, with neck shorter than urn 4

- Capsule elongate-pyriform, with neck equal to urn or longer....

4. Exothecial cells in upper part of urn isodiametric, 1: 1-2 [E. fascicularis]

- Exothecial cells in upper part of urn elongate, 1: 3-5

5. Leaves distinctly bordered, operculum planeconvex [E. obtusus]

- Leaves not bordered, operculum rostrate ... E. hungaricus 
6(3). Leaves lanceolate; peristome \pm developed, ca. $75 \mu \mathrm{m}$, or rudimentary 7

- Leaves obovate, elliptic, ovate or ovate-lanceolate; peristome rudimentary 8

7. Peristome simple, rudimentary, not markedly emergent above the urn mouth; spores 14$18 \mu \mathrm{m}$ [E. angustifolius]

- Peristome double, ca. $75 \mu \mathrm{m}$, markedly emergent above the urn mouth; spores 24-32 $\mu \mathrm{m}$ E. stenophyllus

8. Exothecial cells in upper part of urn thinwalled, with semicircular thickenings in transverse section; spores $18-23 \mu \mathrm{m}$

\section{E. abramovae}

- Exothecial cells in upper part of urn more or less thick-walled, with cuneiform thickenings in transverse section; spores $23-35 \mu \mathrm{m} . . .99$

9. Leaves indistinctly to distinctly bordered, marginal cells in one row yellowish, margins markedly serrate distally E. handelii

- Leaves not bordered, entire or crenulate distally 10

10. Leaves obovate, with maximal width above mid-leaf; costa usually reaching about midleaf, operculum plane-convex

[E. durieui]

- Leaves mostly ovate-lanceolate, with maximal width below mid-leaf; costa reaching ca. $5 / 6$ the leaf length or percurrent; operculum rostrate

E. hungaricus

11(2). Leaves distinctly bordered with 1 row of narrow thick-walled cells; leaf apices acute, with very short apiculus .... [E. attenuatus $]$

- Leaves not bordered or indistinctly bordered with 1 row of narrow cells; leaves shortly acuminate or with long filiform acumen .. 12

12. Leaves shortly acuminate, with entire margins; costa ending well below leaf apex; peristome ca. $320 \mu \mathrm{m}$ long ...... [E. commutatus]

- Leaves with long filiform acumen, margins serrate distally; costa ending just below leaf acumen or percurrent; peristome to $150 \mu \mathrm{m}$ long E. dagestanicus

13(1). Leaves distinctly bordered, in upper part serrate; costa percurrent or ending shortly below leaf acumen E. muhlenbergii

- Leaves indistinctly bordered, in upper part entire to slightly crenulate; costa ending well below apex E. pulchellus

\section{ACKNOWLEDGEMENTS}

We are grateful to Ramazan Murtazaliev for providing field work and to Vladimir P. Prokhorov for the Latin diagnoses. The work was partly supported by the Biodiversity Program of Russian Academy of Sciences and Federal program «Scientific and Educational personalities of innovative Russia 2009-2013 years» (government contracts №14.740.11. 0165 \& №16.740.111.0177).

\section{LITERATURE CITED}

[ABRAMOV, I.I., A.L. ABRAMOVA \& I.V. SIROTINA] АБРАМОВ, И.И., А.Л. АБРАМОВА, И.В. СИРОТИНА 1989. О видах рода Entosthodon Schwaegr (family Funariaceae) из Средней Азии. - [On the species of the genus Entosthodon Schwaegr (family Funariaceae) from the Middle Asia] Новости сист. низш. pacm. [Novosti Sist. Nizsh. Rast.] 26: 124-132.

BRUGUÉS, M. \& E. RUIZ 2010. Entosthodon. - In: Flora Briofitica Ibérica. Vol. 4, Murcia, Unov. Murcia, Soc. Bryol. Española: 44-59.

BRUGUÉS, M. 1998. The identity of Entosthodon durieui and E. pallescens. - Bryologist 101(1): 133-136.

HEYN, C. C. \& I. HERRNSTADT (eds.). 2004. The Bryophyte Flora of Israel and Adjacent Regions. - Jerusalem, Israel Acad. Sci. and Humanities, 719 pp.

IGNATOV, M.S., O.M. AFONINA, E.A. IGNATOVA et. al. 2006. Check-list of mosses of East Europe and North Asia. Arctoa 15: 1-130.

IGNATOV, M.S., V.E. FEDOSOV, E.A. IGNATOVA, G.Ya. DOROSHINA \& V.I. ZOLOTOV 2010. Moss flora of Gunib area in Dagestan, the Eastern Caucasus. - Arctoa 19: 87-96.

[IGNATOV, M.S. \& E.A. IGNATOVA] ИГНАTOB M.C., Е.A. ИГНАТОВА 2003. Флора мхов средней части европейской России. Т. 1.- [Moss flora of the Middle European Russia. Vol. 1] M.: KMK [Moscow, KMK]: 608 pp.

[KHARZINOV, Z. Kh., M.S. IGNATOV, E.A. IGNATOVA \& N.N. PORTENIER] ХАРЗИНОВ 3.Х., Е.А. ИГНАТОВА, M.С. ИГНАТОВ, Н.Н. ПОРТЕНИЕР 2006. НовЫе находки мхов в Кабардино-Балкарской Республике. 1. - [New moss records from Kabardino-Balkarian Republic. 1] Arctoa 15: 256-258.

MILLER, D.H. \& H.A. MILLER 2007. Entosthodon. - In: Flora of North America. Vol. 27. Mosses, part. 1. New York, Oxford, Oxford Univ. Press: 182-188.

PISARENKO, O.Yu., E.A. IGNATOVA \& M.S. IGNATOV 2001. Entosthodon hungaricus (Boros) Loeske (Funariaceae, Musci) in Altaisky Territory (South Siberia). - Arctoa 10: 97-102.

SCHIFFNER, V. 1913. Bryophyta aus Mesopotamien und Kurdistan, Syrien, Rhodos, Mytilini und Prinkipo. - Ann. Naturhist. Hofmus 27: 472-504.

SMITH, A.J.E. 2004. The moss flora of Britain and Ireland. 2 ed. - Cambridge, Cambridge University Press, 1012 pp. 